\title{
Nauczanie na kierunkach politologicznych w Polsce w kontekście oceny jakości kształcenia w latach 2012-2015*
}

Zadanie podjęte w niniejszym artykule dotyczące oceny nauczania akademickiego na kierunkach politologicznych z uwagi na przyjęte ramy musi skutkować szeregiem ograniczeń i czasowych i podjętych wątków tematycznych. Ma zatem charakter syntezy podsumowującej lata 2012-2015.

Już w tym miejscu należy wyjaśnić, co oznacza ujęty w tytule zapis „na kierunkach politologicznych”. W myśl powszechnie obowiązującego w Polsce prawa w zakresie szkolnictwa wyższego ${ }^{1}$ wskazuje się w zakresie nauk społecznych i prawnych w dziedzinie nauk społecznych - nauki o polityce, które, w opinii autora, stanowią absolutny rdzeń i podstawę kształcenia dla szeregu kierunków studiów: politologia, europeistyka, stosunki międzynarodowe, kierunki powiązane $\mathrm{z}$ bezpieczeństwem narodowym i wewnętrznym, a także $\mathrm{z}$ wieloma o innej nazwie, ale efektami kształcenia powiązanymi z państwem, politykami publicznymi, zarządzaniem państwem czy sferą publiczną. Także - na obecnym etapie - relacje pomiędzy „naukami o polityce” a „naukami o polityce publicznej” nie zostały jednoznacznie zakreślone. O ile nauki o polityce publicznej walczą o środowiskowe uznanie i oswojenie się, to na poziomie kształcenia wzajemnie się przenikają, a samo osadzenie kierunków studiów na jednych i drugich bywa często intuicyjne czy wręcz podyktowane celami bardziej utylitarnymi.

* Prezentowany pogląd jest wyłącznie autorski. Oceny odnoszące się do aktywności Polskiej Komisji Akredytacyjnej pochodzą z wykorzystanych w publikacji raportów z działalności PKA oraz raportów powizytacyjnych publikowanych przez PKA na jej stronie internetowej.

1 Rozporządzenie Ministra Nauki i Szkolnictwa Wyższego z dnia 8 sierpnia 2011 roku w sprawie obszarów wiedzy, dziedzin nauki i sztuki oraz dyscyplin naukowych i artystycznych, Dz.U. 2011, nr 179, poz. 1065. 
Nauki o polityce i polityce publicznej są także obecne w na przykład kierunkach odnoszących się do administracji (sfery publicznej), pracy socjalnej, polityki społecznej poprzez wybrane efekty kształcenia ${ }^{2}$, treści nawiązujące do państwa i zarządzania nim. Można zatem uznać, mimo iż klasyczna politologia - w rozumieniu kierunku studiów - przeżywa(-ła) w minionym okresie fazę spadku popularności, to należy na ten fakt patrzeć zdecydowanie szerzej. Politologia ze swego środowiska i zasobów kadrowych wykreowała stosunki międzynarodowe, europeistykę, bezpieczeństwo narodowe, dziennikarstwo, przy zachowaniu - co do zasady zbliżonej bazy potencjalnych kandydatów, tzn. poruszających się na bazie swych zainteresowań i kompetencji w obszarze nauk społecznych.

Powyższe ustalenia powinny zatem $z$ jednej strony pozwolić patrzeć na ten fakt z należną satysfakcją, być może zazdrością, ale i ostrożnością. Obecny stan jednoznacznie sugeruje konieczność troski o dyscyplinę i jakość kształcenia zarówno w instytutach politologii, na kierunkach politologicznych, jak i pokrewnych. Zadanie to jest jednoznacznie i mocno osadzone w przepisach prawa $^{3} \mathrm{w}$ tym miejscu, gdzie ustawodawca zobowiązał uczelnie do osadzenia kierunku studiów (tu efektów kształcenia) w określonych dziedzinach i dyscyplinach naukowych. Fakt ten rodzi kilka konsekwencji: w procesie kształcenia powinni być obecni przedstawiciele nauki o polityce, mogą oni współtworzyć środowisko akademickie, a nawet rdzeń kadrowy, przekazywana jest treść politologiczna, mogą być prowadzone badania naukowe, a prace dyplomowe mogą podejmować zagadnienia właściwe dla współczesnych nauk o polityce.

Podejmując trud oceny kondycji nauczania politologicznego, nie można pominąć uwarunkowań działania szkół wyższych i nauczycieli akademickich. Minione lata cechowała duża dynamika przepisów prawa i głębokich zmian systemowych powiązanych z wprowadzeniem krajowych ram kwalifikacji ${ }^{4}$. Także, co nie pozostawało bez znaczenia na aktywność akademicką

2 Rozporządzenie Ministra Nauki i Szkolnictwa Wyższego z dnia 2 listopada 2011 r. w sprawie Krajowych Ram Kwalifikacji dla Szkolnictwa Wyższego, Dz.U. 2011, nr 253, poz. 1520.

3 Rozporządzenie Ministra Nauki i Szkolnictwa Wyższego z dnia 3 października 2014 r. w sprawie warunków prowadzenia studiów na określonym kierunku i poziomie kształcenia Warszawa, dnia 9 października 2014 r., poz. 1370.

4 Rozporządzenie Ministra Nauki i Szkolnictwa Wyższego z dnia 2 listopada 2011 r. w sprawie Krajowych Ram Kwalifikacji dla Szkolnictwa Wyższego, Dz.U. 2011, nr 253, poz. 1520. 
nauczycieli, na ich barkach spoczywał obowiązek budowy systemów zarządzania dydaktyką spełniających wymogi ocen programowych i instytucjonalnych komisji akredytacyjnej ${ }^{5}$, gruntowne zmiany w zakresie kształcenia na studiach podyplomowych i doktoranckich oraz potwierdzanie efektów uczenia się .

\begin{tabular}{|c|c|}
\hline $\begin{array}{l}\text { Można zatem uznać, że współ- } \\
\text { czesny politolog aktywny } \\
\text { w środowisku akademickim } \\
\text { pracuje wespół z prawnikami, } \\
\text { administratywistami, socjolo- } \\
\text { gami, politykami społecznymi } \\
\text { i nauczającymi w zakresie sze- } \\
\text { roko ujętego bezpieczeństwa. } \\
\text { Jest on obecny w uczelniach } \\
\text { publicznych i niepublicznych, } \\
\text { a na klasycznej politologii } \\
\text { w zdecydowanie większym } \\
\text { stopniu w publicznych szko- } \\
\text { łach i w większych ośrodkach } \\
\text { akademickich }\end{array}$ & $\begin{array}{l}\text { Niestandardowe nazwy kierunków studiów w ramach } \\
\text { obszaru nauk społecznych i prawnych: } \\
\text { administracja europejska, zarządzanie państwem, pro- } \\
\text { jektowanie aktywności społecznej, stosowana psycho- } \\
\text { logia zwierząt, administracja i polityka publiczna; anality- } \\
\text { ka i kreatywność społeczna, coaching, dziennikarstwo } \\
\text { i nowe media, doradztwo i coaching, e-administracja, } \\
\text { bezpieczeństwo w biznesie, bezpieczeństwo zdrowot- } \\
\text { ne, bezpieczeństwo państwa, informatyka w bizne- } \\
\text { sie i administracji, lotnictwo, psychologia w biznesie, } \\
\text { przedsiębiorczość na rynku pracy, prawo w biznesie, } \\
\text { biznes międzynarodowy, coaching i zarządzanie zaso- } \\
\text { bami ludzkimi, kryminologia, logistyka bezpieczeństwa, } \\
\text { mediaworking, mediacje i negocjacje, psychokrymina- } \\
\text { listyka, prawo handlowe i administracja, prawo w dzia- } \\
\text { łalności gospodarczej, prawo publiczne, public rela- } \\
\text { tions i doradztwo medialne, psychologia rynku, wojsko } \\
\text { w systemie służb publicznych, zarządzanie kryzysem } \\
\text { indywidualnym }\end{array}$ \\
\hline
\end{tabular}

Odrębną grupę wyzwań stanowiły te powiązane z budowaniem misji i strategii rozwoju uczelni, kierowanie szkołą wyższą w konwencji zarządzania

5 Rozporządzenie Ministra Nauki i Szkolnictwa Wyższego z dnia 29 września 2011 r. w sprawie warunków oceny programowej i oceny instytucjonalnej, Dz.U., nr 207, poz. 1232. Rozporządzenie Ministra Nauki i Szkolnictwa Wyższego z dnia 3 października 2014 r. w sprawie podstawowych kryteriów i zakresu oceny programowej oraz oceny instytucjonalnej Warszawa, dnia 8 października 2014 r., poz. 1356.

6 Rozporządzenie Ministra Nauki i Szkolnictwa Wyższego z dnia 1 września 2011 r. w sprawie kształcenia na studiach doktoranckich w uczelniach i jednostkach naukowych, Dz.U. 2011, nr 196, poz. 1169; Rozporządzenie Ministra Nauki i Szkolnictwa Wyższego z dnia 1 lipca 2013 r. zmieniające rozporządzenie w sprawie kształcenia na studiach doktoranckich w uczelniach i jednostkach naukowych Warszawa, dnia 26 lipca 2013 r., poz. 841. 
poprzez jakość, budowaniem WSZJK, układanie relacji z interesariuszami wewnętrznymi i zewnętrznymi, monitorowanie losów zawodowych absolwentów i budowanie w oparciu o to ścieżek kształcenia, rozbudowa sprawozdawczości oraz polityki informacyjnej. Suma tychże czynników pozwala uznać warunki pracy nauczycieli akademickich za wysoce niestabilne i absorbujące coraz więcej zaangażowania po stronie obsługi kierunki studiów, a nie „intelektualnego prowadzenia studentów".

Czynnik demograficzny w powiązaniu z nasilającą się konkurencją pomiędzy uczelniami, dynamiką zmian preferencji studentów wraz ze wzrostem ich oczekiwań i niskim nakładem finansowym wyznaczają ostatnią stronę uwarunkowań brzegowych funkcjonowania szkół wyższych w Polsce.

Kierunki politologiczne w minionej kadencji Polskiej Komisji Akredytacyjnej (2012-2015) podlegały ocenie na różne sposoby, w ramach ocen instytucjonalnych, kierunkowych, studiów podyplomowych i doktoranckich. W obszarze nauk społecznych, w ramach ocen instytucjonalnych, dominowały oceny pozytywne. Do słabszych elementów wydziałów tzw. społecznych należały w tym okresie kryteria dotyczące wewnętrznego systemu zapewnienia jakości kształcenia, studiów podyplomowych i doktoranckich, co niosło ze sobą skutek w postaci niewielkiej liczby ocen wyróżniających. Fakt, iż co do zasady nie było istotnych różnic pomiędzy wydziałami/uczelniami, dowodzi obecności w miarę wyrównanego poziomu instytucjonalizacji zarządzania poprzez jakość i jednocześnie podobnych problemów. Głos uczelni w tej kwestii dowodzi jednoznacznie trudności w przyswojeniu nowego paradygmatu i języka opisu założeń oraz efektów kształcenia w środowisku humanistów i przedstawicieli nauk społecznych. Pokazał także swoistą specyfikę nauk społecznych, np. w opozycji do nauk technicznych mogących zawsze jednoznacznie wskazać obiekt techniczny jako przedmiot poznania, a jego doskonałość konstrukcyjno-funkcjonalną za przejaw efektowności kształcenia. Tam, gdzie wydziały uzyskały najwyższe wyniki w ocenie instytucjonalnej, ujawnił się bardzo dobry wpływ dużych uczelni o długiej tradycji akademickiej, zasobach kadrowych i studenckich. W takich uwarunkowaniach łatwiej jest bowiem konstruować bardziej ambitne (ale zarazem realne) efekty kształcenia, wyznaczać cele edukacyjne. Lepsze zasoby kadrowe pozwalały sublimować procedury jakości kształcenia „wymuszające” presję na badania naukowe, dydaktykę i ich wzajemne powiązanie.

Dominującą formą nadzoru nad kształceniem nadal w minionym okresie pozostawała ocena dedykowana wybranemu kierunkowi, tzw. ocena 
programowa. Skala ocen i ich rozbieżność obrazują bardzo duże zróżnicowanie poziomu kształcenia; oczywiście, największa pula uczelni mieściła się w ocenie pozytywnej. $Z$ upływem czasu coraz bardziej popularne stawało się zawieszanie kierunku, jego wygaszanie, likwidacja uczelni. Po wnioskodawczym boomie kolejne lata były okresem kontroli kierunków z dziedziny bezpieczeństwa. Oceny programowe pokazały, że stosunkowo najtrudniej nadal było dobrze konstruować efekty kształcenia, metody dydaktyczne i weryfikacji efektów kształcenia na każdym etapie nauczania.

Infrastruktura, jeśli budziła zastrzeżenia, to szczególnie z uwagi na zasoby biblioteczne, oprzyrządowanie internetowe do wspomagania kształcenia czy nauczania e-learningowego. Stan finansów odbijał się na nieaktualnym księgozbiorze, braku czasopism (w tym obcojęzycznych). Dobrze, że pomocne okazywały się internetowe bazy danych. Mankamentem infrastruktury było dostosowanie do praktycznych profili kształcenia. W mniejszym stopniu dotyczyło to politologii, ale obecne było na kierunkach z zakresu bezpieczeństwa narodowego i wewnętrznego. Także na tych kierunkach zauważono słabość badań naukowych, co dowodzi początkowej fazy rozwoju dyscyplin(-y). Warto jednakże pamiętać, że patrząc ogólnie, stan badań wynikał z zasobów kadrowych, tzn. z liczby nauczycieli (będących zatrudnionymi) oraz z ich palety. Pod tym względem w naukach społecznych zachodzą zróżnicowane procesy, nie zawsze dobrze przekładające się na jakość: kadra niewłaściwa dla koncepcji kształcenia lub dobrana pod „sztucznie” skonstruowany katalog dziedzin i dyscyplin naukowych, brak doświadczenia praktycznego kadry akademickiej, niedostateczna weryfikacja kwalifikacji praktyków, osoby spoza RP, lokowanie kadry zaawansowanej wiekowo poza dużymi ośrodkami akademickimi w uczelniach niepublicznych. Kierunki politologiczne pod tym względem nie wyróżniały się.

Wbrew rozpowszechnianej opinii decydentów politycznych, polska politologia kształciła w minionym okresie na poziomie pozwalającym przyznać oceny wyróżniające. Warto także w tym miejscu wskazać, że z tego środowiska nieustanie rekrutują się elity polityczne: Kraków, Wrocław, Warszawa, Poznań. Dostrzeżenie wkładu polskiej politologii do kształcenia akademickiego przyszło także w zakresie uznania przyjętych w uczelniach rozwiązań za dobre praktyki, za wzorcowe opracowanie efektów kształcenia, za poszukiwanie niszy edukacyjnych. 
Wyróżnienia: Wydział Nauk Społecznych Uniwersytetu Wrocławskiego - kierunek politologia; Wydział Dziennikarstwa i Nauk Politycznych Uniwersytetu Warszawskiego - kierunek politologia; Wydział Studiów Międzynarodowych i Politycznych Uniwersytetu Jagiellońskiego w Krakowie wyróżnienie w ramach oceny instytucjonalnej

W kadencji PKA (2008-2012) inne dwa ośrodki akademickie uzyskały ocenę wyróżniającą na kierunku politologia

Oceny wyróżniające wydane przez ZNSiP dla kierunków: dziennikarstwo i komunikacja społeczna, socjologia, prawo, administracja, pedagogika, polityka społeczna, bezpieczeństwo narodowe

Dobre praktyki: Wydział Studiów Międzynarodowych i Politycznych Uniwersytetu Jagiellońskiego w Krakowie za dobrą praktykę uznano „Ocenę przygotowania i prowadzenia przedmiotu"

Uznanie Ministra za „wzorcowe” opracowanie efektów kształcenia: Wydział Nauk Społecznych Uniwersytetu Wrocławskiego Wydział Studiów Międzynarodowych i Politycznych Uniwersytetu Jagiellońskiego w Krakowie

Uznanie Ministra za ciekawą koncepcję kształcenia: Wydział Nauk Politycznych i Dziennikarstwa w Poznaniu za studia w systemie dualnym oraz Wydział Nauk Społecznych w Lublinie za studia wschodnioeuropejskie

Można zatem uznać, iż stan polskiej politologii z perspektywy zasobów nie jest zły. Doświadczana redukcja kandydatów na studia obejmuje zdecydowaną większość kierunków i krajowych uczelni, a politolodzy wykazali się w tym zakresie dość dobrą zdolnością adaptacyjną i odpowiedzią na potrzeby przemian społecznych i cywilizacyjnych. Oczywiście, nie zwalania to od dalszej troski i o jakość dyscypliny, i poziomu nauczania, pozwala jednak żywić nadzieję na trwałą obecność politologii w ofercie dydaktycznej najlepszych polskich szkół wyższych.

\section{Bibliografia}

Działalność Polskiej Komisji Akredytacyjnej w latach 2012-2015 IV Kadencja, red. B. Wojciechowska, Warszawa 2016.

Młodość czy doświadczenie? Kapitał ludzki w Polsce. Raport podsumowujący III edycję badań BKL z 2012 roku, red. J. Górniak, Kraków 2013. Monitorowanie karier zawodowych absolwentów przez polskie uczelnie wyzsze w świetle wyników badania Biura Analiz Sejmowych, red. D. Dziewulak, A. Grycuk, P. Russel, Z. Wołodkiewicz-Donimirski, „Analizy. Biuro Analiz Sejmowych" 2014, nr 5(109). 
Monitorowanie losów absolwentów uczelni wyższych z wykorzystaniem danych administracyjnych Zakładu Ubezpieczeń Społecznych, red. M. Bożykowski, M. Dwórznik, E. Giermanowska, A. Izdebski, M. Jasiński, J. Konieczna-Sałamatin, M. Styczeń, T. Zając, Raport końcowy, Warszawa 2014.

Plan realizacji gwarancji dla młodzieży w Polsce, Ministerstwo Pracy i Polityki Społecznej, Ministerstwo Infrastruktury i Rozwoju, Warszawa 2014. Rozporządzenie Ministra Nauki i Szkolnictwa Wyższego z dnia 8 sierpnia 2011 roku w sprawie obszarów wiedzy, dziedzin nauki i sztuki oraz dyscyplin naukowych i artystycznych, Dz.U. 2011, nr 179, poz. 1065.

Rozporządzenie Ministra Nauki i Szkolnictwa Wyższego z dnia 1 września 2011 r. w sprawie kształcenia na studiach doktoranckich w uczelniach i jednostkach naukowych, Dz.U. 2011, nr 196, poz. 1169.

Rozporządzenie Ministra Nauki i Szkolnictwa Wyższego z dnia 29 września 2011 r. w sprawie warunków oceny programowej i oceny instytucjonalnej, Dz.U. 2011, nr 207, poz. 1232.

Rozporządzenie Ministra Nauki i Szkolnictwa Wyższego z dnia 2 listopada 2011 r. w sprawie Krajowych Ram Kwalifikacji dla Szkolnictwa Wyższego, Dz.U. 2011, nr 253, poz. 1520.

Rozporządzenie Ministra Nauki i Szkolnictwa Wyższego z dnia 1 lipca 2013 r. zmieniające rozporządzenie w sprawie kształcenia na studiach doktoranckich w uczelniach i jednostkach naukowych Warszawa, dnia 26 lipca 2013 r., poz. 841.

Rozporządzenie Ministra Nauki i Szkolnictwa Wyższego z dnia 3 października 2014 r. w sprawie podstawowych kryteriów i zakresu oceny programowej oraz oceny instytucjonalnej Warszawa, dnia 8 października 2014 r., poz. 1356.

Rozporządzenie Ministra Nauki i Szkolnictwa Wyższego z dnia 3 października 2014 r. w sprawie warunków prowadzenia studiów na określonym kierunku i poziomie kształcenia Warszawa, dnia 9 października 2014 r., poz. 1370.

Statut Polskiej Komisji Akredytacyjnej, Załącznik do uchwały Nr 1/2015 Polskiej Komisji Akredytacyjnej z dnia 23 lutego 2015 r., http://www.pka.edu. pl/wp-content/uploads/2015/03/statut_full_2015.pdf .

Szewior K., Ocena przygotowania i prowadzenia przedmiotu - Uniwersytet Jagielloński w Krakowie, Wydział Studiów Międzynarodowych 
i Politycznych, [w:] Wybrane „dobre praktyki” zarządzania jakością kształcenia w polskich szkołach wyższych, Polska Komisja Akredytacyjna, Warszawa 2015.

Szewior K., Zespół działający w ramach obszaru nauk społecznych $w$ zakresie nauk społecznych, [w:] Działalność Polskiej Komisji Akredytacyjnej w 2012 roku, red. K. Nowak, A. Gawryszewski, opracowanie materiału w ramach Zespołu PKA, Warszawa 2013.

Szewior K., Zespół działający w ramach obszaru nauk społecznych w zakresie nauk społecznych i prawnych, [w:] Działalność Polskiej Komisji Akredytacyjnej w 2013 roku, współredakcja A. Gawryszewski, opracowanie materiału w ramach Zespołu PKA, Warszawa 2014.

Szewior K., Zespół działający w ramach obszaru nauk społecznych w zakresie nauk społecznych i prawnych, [w:] Działalność Polskiej Komisji Akredytacyjnej w 2014 roku, red. K. Nowak, A. Gawryszewski, opracowanie materiału w ramach Zespołu PKA, Warszawa 2015.

Ustawa z dnia 27 lipca 2005 r. Prawo o szkolnictwie wyższym, Dz.U. 2005, nr 164, poz. 1365.

\section{Streszczenie}

Celem publikacji jest analiza specyfiki i jakości kształcenia na kierunkach politologicznych w okresie 2012-2015 oraz podsumowanie. Autor zobrazował stan polskiej politologii w perspektywie poziomu nauczania na kierunkach ocenionych przez PKA, a także ogólnej refleksji o nauczaniu akademickim w dziedzinie nauk społecznych. Nauki o polityce są obecnie podstawą kształcenia na politologii, ale jednocześnie stanowią rdzeń dydaktyczny i naukowo-badawczy innych kierunków studiów. Fakt ten zobowiązuje nas do wzięcia pod uwagę i uwzględnienia studentów. Nauki polityczne pojawiają się w różnych konstelacjach badań i zasobów ludzkich. Sytuacja ta powinna być źródłem i satysfakcją w działalności na rzecz rozwoju i spójności dyscypliny naukowej w obliczu deregulacji i otwarcia ścieżki akademickiej. Zewnętrzna ocena szkolnictwa wyższego daje pozytywne pojęcie wkładu politycznego w badania nauk społecznych i potwierdza poziom wykształcenia w ośrodkach uniwersyteckich. Wiele uczelni wyższych uzyskało najwyższy poziom, są znaczącymi ośrodkami akademickimi i rozwijały dobre praktyki w dziedzinach kształcenia i badań naukowych. W tym czasie dążenie do spójności dyscypliny i jej 
dalszego rozwoju uznano za główny cel w obliczu kryzysu popularności klasycznej nauki politycznej.

Słowa kluczowe: nauki o polityce, polityki publiczne, jakość kształcenia

\begin{abstract}
The aim of this article is the analysis of the specificity and quality of education in political science in the period 2012-2015. The publication is the summary, the author illustrates the status of political science in Poland in the perspective of the level of teaching in the fields of the evaluation and estimation of the quality in higher education by PKA, as well as the general reflection on academic teaching in the field of social sciences. Nowadays political sciences are the essential element of education in politics areas, but together the core of didactic and scientific research in other scientific disciplines. This fact obliges us to look and take responsibility for students. The political science appear in various constellations of research and human resources. This situation should be sources and satisfaction in activity for development and coherence of scientific discipline in the face of deregulation and the opening of academic path. The external evaluation of higher education gives a positive notion of a political contribution to the study of social sciences and certifies the level of education in university centers. A number of universities have received the highest rate, they are significant academic centers, and have developed good practices in teaching and research. At that time, the endeavor to the consistency of discipline and its further development was recognized as main purpose in the face of the crisis in popularity of classical political science.
\end{abstract}

Keywords: political science, public policy, quality of education 